\title{
EPIDEMIOLOGICAL, CLINICAL AND MORPHOLOGICAL CHARACTERISTICS OF IMMUNOGLOBULIN A NEPHROPATHY IN LATVIA
}

\author{
Linda Kučāne ${ }^{1}$, Anna Popova ${ }^{1,2,3, \#}$, Viktorija Kuzema ${ }^{1,3}$, Aivars Lejnieks ${ }^{3,4}$, \\ and Aivars Pētersons ${ }^{1,3}$ \\ ${ }^{1}$ Pauls Stradiṇš Clinical University Hospital, 13 Pilsoṇu Str., Rīga, LV-1002, LATVIA \\ ${ }^{2}$ Faculty of Medicine, University of Latvia, 19 Raiṇa Blvd., Rīga, LV-1586, LATVIA \\ ${ }^{3}$ Faculty of Medicine, Rīga Stradiṇš University, 16 Dzirciema Str., Rīga, LV-1007, LATVIA \\ ${ }^{4}$ Rīga East Clinical University Hospital, 2 Hipokrāta Str., Rīga, LV-1038, LATVIA \\ \# Corresponding author, annasild@yahoo.co.uk
}

Contributed by Aivars Lejnieks

\begin{abstract}
Immunoglobulin A nephropathy (IgAN) is the most common chronic glomerulopathy with variable clinical manifestations. IgAN diagnostics became possible in Latvia in 2013. The study aim was to describe IgAN manifestations in the Latvian population by analysing epidemiological, clinical, histological data, and reveal factors that might determine the course of the disease. The retrospective, one-centre study included biopsy-proven IgAN patients over a five-year period in the Nephrology Centre at Pauls Stradinš Clinical University Hospital. Data from inpatient and outpatient medical records were collected. The study included 69 patients with histologically confirmed $\operatorname{IgAN}(23 \%$ of all renal biopsies): $52 \%$ men with mean age of 37 . More than a half of them had hypertension, changes in urinalysis and kidney structure, and GFR $<\mathrm{ml} / \mathrm{min}$ before the biopsy. Pathology data stratified by MEST-C score were: M1 (93\%), E1 (5\%), S1 (81\%), T1 and T2 (24\%), C1 (18\%). 20\% started renal replacement therapy (RRT). Proteinuria, obesity, hyperuricemia, high total MEST-C score, and low serum C3 were associated with a worse prognosis. As a significant part of patients start RRT in the five-year period after the biopsy, the disease course is not benign. IgAN in the study population was diagnosed with clinical and histological signs of advanced disease.
\end{abstract}

Key words: glomerulonephritis, immunoglobulin A, kidney biopsy, nephrology, kidney disease.

\section{INTRODUCTION}

Immunoglobulin A nephropathy (IgAN) is the most common of all primary glomerulonephritis in developed countries. It varies largely in geographical distribution, as it is more frequent in the Asian population (45 cases per million) than in Caucasians (31 cases per million) (Schena and Nistor, 2018). In some autopsy and biopsy studies, IgAN can be found in about $1.5 \%$ of the normal population (Suzuki et al., 2003). It is a mesangioproliferative glomerulonephritis with characteristic diffuse IgA deposits in the mesangium. It was first described in 1968 by Jean Berger and Nicole Hinglais, when immunofluorescence was introduced in the examination of kidney biopsy material.
Earlier it was called benign disease with recurrent haematuria, but now it is known that in $40 \%$ cases IgAN leads to end-stage renal disease (ESRD) (Feehally et al. 2018).

IgAN is diagnosed using immunofluorescence (IF), which for Latvian patients has been routinely and reliably available only since 2013, after the Nephrology Centre in Pauls Stradiňš Clinical University Hospital (PSCUH) started tight cooperation with the National Centre of Pathology in Vilnius, Lithuania.

It has been 50 years since the discovery of $\operatorname{IgAN}$, but there are still many unanswered questions. IgAN has different 
pathogenic mechanisms and prognostic factors in different geographic regions. The study of IgAN pathogenesis, clinical, histological, and genetic prognostic markers and treatment continues worldwide. Clinically IgAN can be manifested from asymptomatic changes in urinalysis to rapidly progressive glomerulonephritis. It is very important to diagnose IgAN, evaluate factors that determine renal prognosis and start timely treatment that can slow or prevent progression to ESRD, which affects quality of life, ability to work and life expectancy, as well as health care costs.

Considering different and sometimes even conflicting world research data, the goal of this study was to uncover the manifestations of IgAN in our population. The aim of this study was to analyse epidemiological, clinical, and histological data of IgAN patients and to discover factors that might determine the course and prognosis of the disease.

\section{MATERIALS AND METHODS}

The study was retrospective and involved a single centre. Patients at least 18 years old with morphologically confirmed $\operatorname{Ig} \mathrm{AN}$ by the presence of $\operatorname{IgA}$ deposits shown by immunofluorescence microscopy at the Nephrology Centre of Pauls Stradinš Clinical University Hospital in the period from January 2013 to December 2017 were included. The decision to perform the biopsy as well as treatment management were determined by the treating physician based on the following specific indications: impaired kidney function or changes in urinalysis. The inpatient and outpatient medical records included the following data: demographic characteristics, comorbidities, previous and current treatment, history of hypertension and abnormal urinalysis, time of the dialysis or transplantation after the biopsy, ultrasound and laboratory results (urinalysis, estimated glomerular filtration rate (eGFR) using CKD-EPI formula, complement fractions, and other immunology markers), histological data and serum creatinine available until January 2018. The Oxford classification was used for biopsy evaluation. It was first published in 2009, then confirmed and supplemented with subsequent cohorts, and is used to predict clinical outcome by MEST-C scoring: mesangial hypercellularity (M), endocapillary cellularity (E), segmental sclerosis (S), interstitial fibrosis/tubular atrophy (T) and crescents (C) (Trimarchi et al., 2017). The collected data were analysed using IBM SPSS Statistics 20. To compare groups, we used non-parametrical tests (Mann-Whitney, Kruskal-Wallis and Crosstabs), for correlations - Spearman correlation coefficient, and for renal survival - the Kaplan-Meier estimator. The present study was approved by the PSCUH Ethics Committee (approval nr. 100118-10L; January 10, 2018).

\section{RESULTS}

In total, 303 renal biopsies were performed in the Nephrology Centre at Pauls Stradiņš Clinical University Hospital from 2013 to 2017 ; $23 \%$ of the patients $(n=69)$ had IgAN diagnosis. Mean age was $37(31-46)$ years and 52\% $(\mathrm{n}=$
36) of the sample group were men. Mean BMI was 25.8 $(22.8-29.7) \mathrm{kg} / \mathrm{m}^{2}(\mathrm{n}=59)$. Furthermore, 55\% $(\mathrm{n}=38)$ of patients had no previous comorbidities. The remaining patients had other diseases like gastrointestinal pathologies, infections (hepatitis B or C, HIV, urinary tract infections, recurrent tonsillitis), bronchial asthma, epilepsy, diabetes, psoriasis, celiac disease and thyroiditis. At the time of biopsy $97 \%(n=67)$ of patients had proteinuria, and average daytime proteinuria was $1.3(0.6-3.7) \mathrm{g} /$ day $(\mathrm{n}=46)($ Table $1)$.

Before the biopsy, 74\% ( $\mathrm{n}=51)$ of patients had known hypertension on average for three (1-7) years. Moreover, $67 \%$ $(\mathrm{n}=46)$ patients were taking antihypertensive medication before the biopsy, 58\% ( $\mathrm{n}=40)$ received angiotensin-converting enzyme inhibitors, and $39 \%(n=27)$ were taking two or more medications to control blood pressure. Of all the patients, $71 \%(\mathrm{n}=49)$ had known changes in urinalysis on average for 24 (5-72) months. Ultrasound showed that $41 \%$ (22 of 53) of patients had signs of chronic kidney damage at the time of biopsy.

On average, there were 14 (9-21) glomeruli in kidney biopsy reports, and $17 \%(n=12)$ contained less than eight glomeruli, which is considered insufficient to use Oxford classification. Histological examination showed that $20 \%$ $(n=4)$ of biopsies had more than half of glomeruli globally sclerosed, and segmental glomerulosclerosis were present in

Table 1. Baseline characteristics of the study group

\begin{tabular}{|c|c|}
\hline Characteristics & n $(\%)$ \\
\hline Age & $37(31-46)$ \\
\hline Male & $36(52)$ \\
\hline No comorbidities & $38(55)$ \\
\hline Proteinuria & $67(97)$ \\
\hline $24 \mathrm{~h}$ proteinuria & $46(67)$ \\
\hline$<0.5 \mathrm{~g} / 24 \mathrm{~h}$ & $8(17.5)$ \\
\hline $0.5-1 \mathrm{~g} / 24 \mathrm{~h}$ & $8(17.5)$ \\
\hline $1-3 \mathrm{~g} / 24 \mathrm{~h}$ & $16(35)$ \\
\hline$>3 \mathrm{~g} / 24 \mathrm{~h}$ & $14(30)$ \\
\hline \multicolumn{2}{|l|}{ Clinical manifestation } \\
\hline nephritic syndrome & $48(70)$ \\
\hline nephrotic proteinuria and haematuria & $10(14)$ \\
\hline nephrotic syndrome & $1(1)$ \\
\hline asymptomatic urinalysis changes & $9(13)$ \\
\hline isolated proteinuria with decreased GFR & $1(1)$ \\
\hline \multicolumn{2}{|l|}{ GFR at the time of biopsy $\left(\mathrm{ml} / \mathrm{min} / 1.73 \mathrm{~m}^{2}\right)$} \\
\hline$>90$ & $17(25)$ \\
\hline $60-89$ & $12(17)$ \\
\hline $30-59$ & $18(26)$ \\
\hline $15-29$ & $17(25)$ \\
\hline$<15$ & $5(7)$ \\
\hline Hypertension at the time of biopsy & $51(74)$ \\
\hline antihypertensive drugs & $46(67)$ \\
\hline ACE inhibitors or ARBs before the biopsy & $40(58)$ \\
\hline ACE inhibitors or ARBs after the biopsy & $51(74)$ \\
\hline two or more antihypertensive drugs & $27(39)$ \\
\hline
\end{tabular}


Table 2. Histopathological characteristics of the study group

\begin{tabular}{|l|l|}
\hline Deposits & $\mathrm{n}(\%)$ \\
\hline IgA & $69(100)$ \\
IgM & $43(62.3)$ \\
IgG & $6(8.7)$ \\
C3 & $33(47.8)$ \\
light chains $(\kappa$ or $\lambda)$ & $25(36.2)$ \\
\hline MEST-C score & \\
\hline M1 & $53(93)$ \\
E1 & $3(5)$ \\
S1 & $46(81)$ \\
T1 & $7(12)$ \\
T2 & $7(12)$ \\
C1 & $10(18)$ \\
C2 & $0(0)$ \\
\hline
\end{tabular}

$81 \%(n=46)$ of biopsies. Light microscopy showed mesangial hypercellularity and an increase in mesangial matrix was frequently seen $(93 \%)$; endocapillary infiltration was less common (5\%). Mesangial Glomerular deposits were observed under immunofluorescence; MEST-C scores in patients with more than eight glomeruli in biopsies $(\mathrm{n}=$ 57) are shown in Table 2. IgA mesangial deposits are the characteristic and defining feature of the disease; nevertheless, $\operatorname{Ig} \mathrm{A}$ deposits were accompanied by $\operatorname{IgM}$ deposits in $62.3 \%$ of cases, and $\mathrm{IgG}$ deposits in $8.7 \%$.

Immunosuppression was received by $17 \%(n=12)$ of patients, mostly after diagnosis histological confirmation. The indications for it were nephrotic range proteinuria and rapid decline of renal function. Only one patient received immunosuppression three years prior to biopsy, but it was terminated later. Three patients started renal replacement therapy (RRT) and one died. There was no unified treatment protocol; patients received different treatment agents: glucocorticoids in combination with cyclophosphamide $(\mathrm{n}=$ $6)$, glucocorticoids in monotherapy $(n=4)$, and glucocorticoids in combination with cyclosporine and then changed to mycophenolate mofetil (MMF) $(n=1)$.

During the follow-up period, 20\% $(n=14)$ patients had decline in eGFR and developed ESRD, and RRT was started on average 11 months after the biopsy was performed. Three patients were dialysis dependent at the time of biopsy. In the next years after the biopsy, $9 \%$ of patients $(n=$ 6) received a kidney transplant. Unfortunately, $43 \%$ ( $\mathrm{n}=$ 30) of patients had no available data about their kidney function after the biopsy. Analysis of available follow-up showed that data kidney function in most cases continued to decline in the following years after the biopsy (Table 3).

Table 3. Changes in creatinine level after kidney biopsy

\begin{tabular}{|l|l|l|l|}
\hline Changes of creatinine & $\begin{array}{l}1^{\text {st }} \text { year, } \\
\mathrm{n}=19\end{array}$ & $\begin{array}{l}2^{\text {nd }}-3^{\text {rd }} \text { year, } \\
\mathrm{n}=12\end{array}$ & $\begin{array}{l}3^{\text {rd }}-5^{\text {th }} \\
\mathrm{n}=6\end{array}$ \\
\hline Elevated $<50 \%$ & 9 & 4 & 2 \\
\hline Elevated $=50 \%$ & 2 & 3 & 3 \\
\hline No significant change & 4 & 3 & 1 \\
\hline Lowered & 4 & 2 & 0 \\
\hline
\end{tabular}

Table 4. Observed differences between mean values of creatin, proteinuria, age and serum $\mathrm{C} 4$ in the study group.

\begin{tabular}{|c|c|c|c|}
\hline Factor & Groups & Median & $p$ \\
\hline \multirow[t]{3}{*}{$\begin{array}{l}\text { Creatinine, } \\
\mathrm{mcmol} / \mathrm{l}\end{array}$} & $\begin{array}{l}\text { Male } \\
\text { Female }\end{array}$ & $\begin{array}{l}153(99-301) \\
115(67-194)\end{array}$ & 0.01 \\
\hline & $\begin{array}{l}\text { Hyperuricemia patients } \\
\text { Normal serum uric acid }\end{array}$ & $\begin{array}{l}309(257-354) \\
138(96-196)\end{array}$ & 0.001 \\
\hline & $\begin{array}{l}\text { MEST-C T0 } \\
\text { MEST-C T1 } \\
\text { MEST-C T2 }\end{array}$ & $\begin{array}{l}104(80-165) \\
198(110-313) \\
350(309-528) \\
\end{array}$ & $<0.001$ \\
\hline Proteinuria, g/d & $\begin{array}{l}\text { C3 deposits+ } \\
\text { C3 deposits - }\end{array}$ & $\begin{array}{l}2.1(1.0-4.1) \\
1.2(0.3-2.3) \\
\end{array}$ & 0.037 \\
\hline \multirow[t]{2}{*}{ Age, years } & $\begin{array}{l}\text { Lights chain deposits + } \\
\text { Light chain deposits - }\end{array}$ & $\begin{array}{l}47(40-53) \\
33(29-38) \\
\end{array}$ & $<0.001$ \\
\hline & $\begin{array}{l}\text { MEST-C M0 } \\
\text { MEST-C M1 }\end{array}$ & $\begin{array}{l}49(42-56) \\
36(30-45) \\
\end{array}$ & 0.026 \\
\hline Serum C4, g/1 & $\begin{array}{l}\text { MEST-C C0 } \\
\text { MEST-C C } 1\end{array}$ & $\begin{array}{l}0.24(0.20-0.30) \\
0.30(0.30-0.34)\end{array}$ & 0.02 \\
\hline
\end{tabular}

We found statistically significant correlations $(p<0.05)$, despite the rather small study group: 1) higher BMI was associated with higher serum C3 and less glomeruli in biopsy, 2) longer history of hypertension before the biopsy was associated with longer time until RRT, 3) more globally sclerosed glomeruli in biopsy were associated with lower eGFR and shorter time until RRT, 4) more crescents in biopsy were associated with a higher serum complement $\mathrm{C} 4$ fraction, 5) creatinine elevation in the $1^{\text {st }}$ year after the biopsy was associated with younger age and more severe proteinuria, and 6) creatinine elevation in the third to fifth year after the biopsy was associated with lower serum complement C3 fraction.

Comparing different groups, we found that creatinine was higher in males, patients with hyperuricemia and higher $\mathrm{T}$ score; proteinuria was more severe in patients with glomerular C3 deposits and serum C4 was higher in patients with crescents in biopsy (Table 4). More severe 24-hour proteinuria was more common in adipose patients $(\mathrm{BMI}>$ $25 \mathrm{~kg} / \mathrm{m}^{2}$ ), comparing to patients with normal BMI ( $p=$ 0.007).

Analysis of renal survival in the group of patients who received RRT showed that hyperuricemia as well as T and E lesions in Oxford classification were associated with worse renal survival (Fig. 1).

\section{DISCUSSION}

This is the first study that shows Latvian data about IgAN epidemiology, clinical manifestation, and prognosis. In our population, $\operatorname{IgAN}$ was observed in $23 \%$ of all biopsies, which is similar to other European data (Fiorentino et al., 2016) and corresponds to $0.003 \%$ of the Latvian population. There was no significant difference between genders and the mean age of diagnosis: 31-46 years. Literature shows that IgAN usually manifests in the $2^{\text {nd }}$ and $3^{\text {rd }}$ decades (James et al., 2002), which might indicate later diagnosis in our population. Nephritic syndrome was the most common 


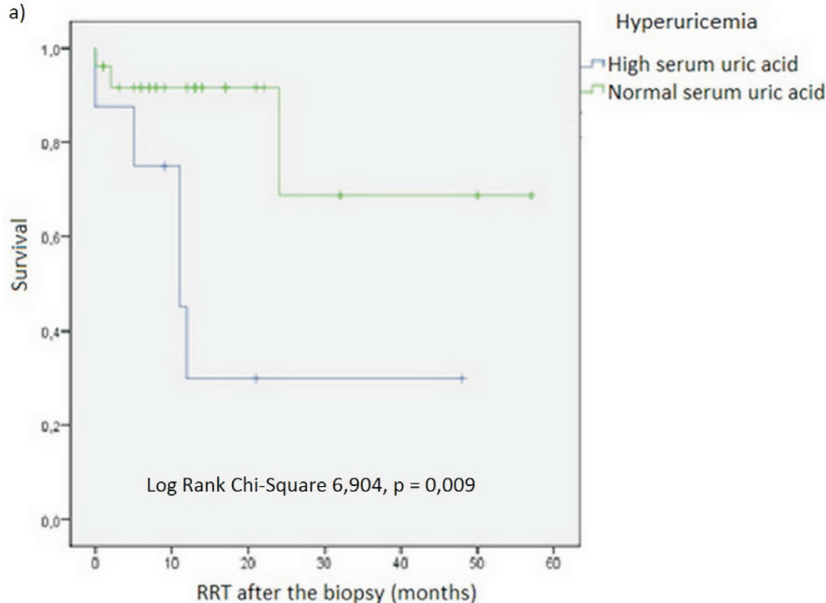

b)

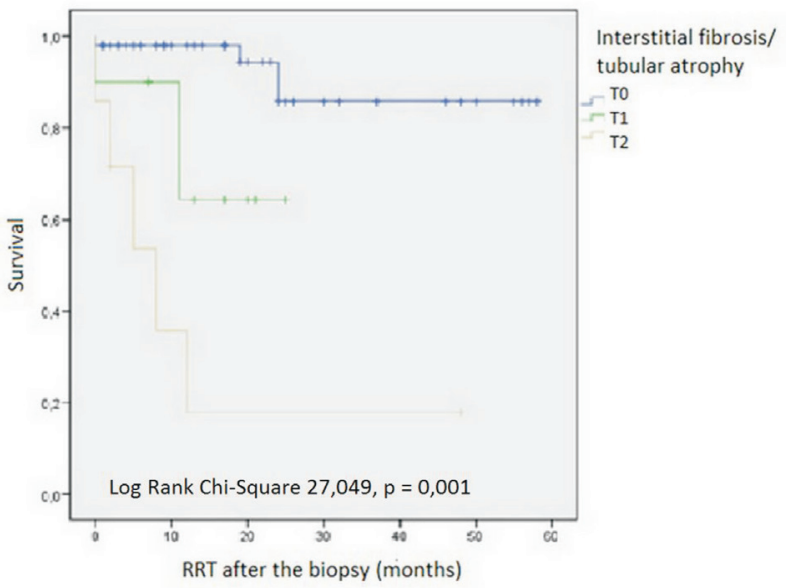

c)

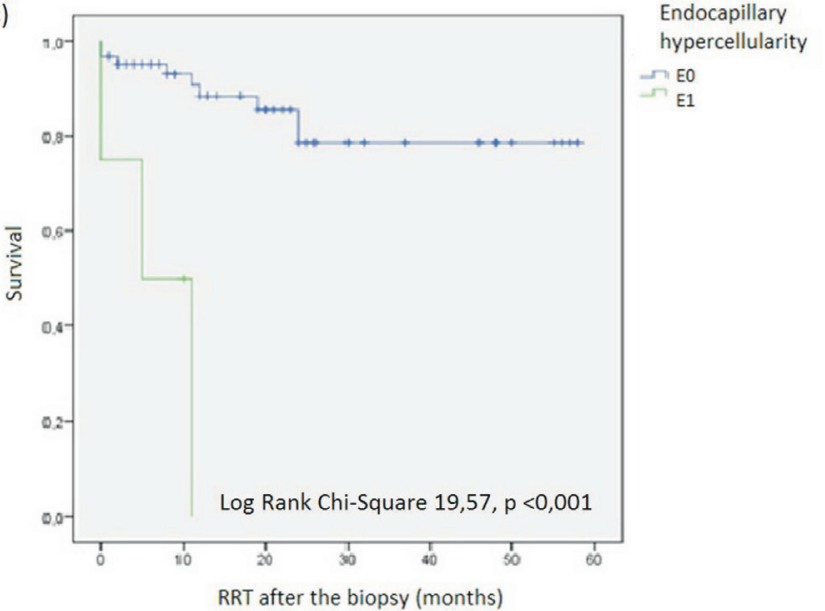

Fig. 1. Analysis of renal survival and a) hyperuricemia; b) tubular atrophy and interstitial fibrosis, and c) endocapillary hypercellularity in renal biopsy material of patients who started renal replacement therapy in the five-year period after renal biopsy.

clinical presentation and only $13 \%$ of patients had asymptomatic changes in urinalysis, compared to $30-40 \%$ reported elsewhere (Trimarchi et al., 2017). It can be thus assumed that these patients in our population were not diagnosed or were not referred for renal biopsy.

The majority of the patients had a history of hypertension and abnormal urinalysis until the biopsy, which might indicate that the length of the disease might be $2-3$ years on av- erage. Upon the time of biopsy, $58 \%$ of patients had eGFR less than $60 \mathrm{ml} / \mathrm{min} / 1.73 \mathrm{~m}^{2}$ and $7 \%$ - ESRD, which indicated far advanced disease and worse renal prognosis. The same conclusions can be made from histological data, as $81 \%$ had segmental glomerulosclerosis and $24 \%$ had tubular atrophy and/or interstitial fibrosis.

Most often, the seen glomerular deposits were $\operatorname{IgM}$ (62\% of biopsies), which in some studies were associated with sclerotic lesions (Arijana et al., 2017). In the literature, only less than 5\% IgAN patients developed acute kidney failure with crescentic lesions (Feehally et al., 2018), while in our study, $18 \%$ has crescents, which can be explained by a large amount of undiagnosed patients with better prognosis.

Treatment was usually conservative, with only $17 \%$ receiving immunosuppressant drugs in different regimens, mostly in severe proteinuria or with progressive decline of renal function, leading to different outcomes. However, this group was too small to make any conclusions.

In literature data, 1/4 (e.g., Steddon et al., 2014) and in our study $1 / 5$ of IgAN patients, progressed to ESRD and started RRT on average one year after the biopsy. Most of the patients who did not progress to ESRD had a tendency of declining renal function in the following years after the biopsy. This group also was too small to conduct more analysis and draw conclusions.

Some of the study results seem to be well known, for example, the association between sclerosed glomeruli and eGFR, but others are new findings that require future investigation. Considering the results, lower serum $\mathrm{C} 3$ and higher serum C4 were associated with worsening kidney function. Furthermore, more crescents were associated with higher serum C4, which was also found in a study in China (Pan et al., 2017). Evidence suggests that IgAN is associated with an increase in the activation of the mannose-binding lectin (MBL) pathway, measured as C4d and MBL deposition in glomerulus, so the increase in serum levels of MBL is associated with higher levels of serum complement $\mathrm{C} 4$.

Higher BMI is associated with more severe proteinuria linked to glomerular hyperfiltration, as well as a higher level of hyperuricaemia, and serum C3. Many reports have shown that there is a strong relationship between $\mathrm{C} 3$ and acylation-stimulating protein (C3a-desArg) levels, adipose tissue, and risk factors for cardiovascular disease, metabolic syndrome and diabetes. The C3 fragment, C3a-desArg, functions as a hormone that has insulin-like effects and facilitates triglyceride metabolism. Adipose tissue produces and regulates the levels of complement components, which promotes generation of inflammatory initiators such as the anaphylatoxins C3a and C5a. The anaphylatoxins trigger a cyto/chemokine response in proportion to the amount of adipose tissue present, and induce inflammation (Barbu et al., 2015).

The disadvantages of our study were a small amount of IgAN patients, small group sizes, short retrospective obser- 
vational follow-up period, and some unavailable data. However, for the first time our study presents the epidemiologic situation and manifestation of the most common type of glomerulonephritis in the Latvian population, since precise diagnostics of this disease became available only in 2013 due to successful international collaboration.

There are also some research ideas for the future. As IgAN is not a so benign disease, it would be useful to identify immunologic or genetic criteria that worsen prognosis, in order to focus on body weight reduction for the patients with changes in urinalysis or decreased kidney function.

In conclusion, a significant part of patients begin renal replacement therapy in the five-year period after the biopsy, and the disease is not so benign. Proteinuria, adiposity, hyperuricaemia, higher MEST-C score in histological examination, lower complement $\mathrm{C} 3$, and signs of chronic kidney disease at the time of diagnosis are markers of worse IgAN prognosis. IgAN in the Latvian population is diagnosed with clinical and histological signs of advanced disease.

\section{REFERENCES}

Arijana, P., Šenjug, P., Bacalja, J., Tišljar, M., Horvatić, I., Bulimbašić, S., Knotek, M., Galešić, K., Ljubanović (2017). IgM as a novel predictor of disease progression in secondary focal segmental glomerulosclerosis. Croatian Med. J., 58 (4), 281-291.
Barbu, A., Hamad, O. A., Lind, L., Ekdahl, K. N., Nilsson, B. (2015). The role of complement factor C3 in lipid metabolism. Mol. Immunol., 67 (1), 101-107.

Feehally, J., Floege, J., Tonelli, M., Johnson, R. J. (2018). Comprehensive Clinical Nephrology. $6^{\text {th }}$ ed. Elsevier, Philadelphia. 1360 pp.

Fiorentino, M., Bolignano, D., Tesar, V., Pisano, A., Biesen, W. V., D’Arrigo, G., Tripepik, G., Gesualdo, L., ERA-EDTA Immunonephrology Working Group (2016). Renal biopsy in 2016 - from epidemiology to evidence-based indications. Amer. J. Nephrol., 43 (1), 1-19.

Donadio, J. V., Grande, J. P. (2002). IgA Nephropathy. New Engl. J. Med., 347 (10), 738-748.

Pan, M., Zhang, J., Li, Z., Jin, L., Zheng, Y., Zhou, Z., Zhen, S., Lu, G. (2017). Increased C4 and decreased C3 levels are associated with a poor prognosis in patients with immunoglobulin A nephropathy: A retrospective study. BMC Nephrology, 18 (1), 231.

Schena, F. P., Nistor, I. (2018). Epidemiology of IgA nephropathy: A global perspective. Seminars Nephrol., 38 (5), 435-442.

Steddon, S., Ashman, N., Chesser, A., Cunningham, J. (2014). Oxford Handbook of Nephrology and Hypertension. $2^{\text {nd }}$ ed. (pp. 544). Oxford University Press, Oxford. 1008 pp.

Suzuki, K., Honda, K., Tanabe, K., Toma, H., Nihei, H., Yamaguchi, Y. (2003). Incidence of latent mesangial IgA deposition in renal allograft donors in Japan. Kidney Int., 63 (6), 2286-2294.

Trimarchi, H., Barratt, J., Cattran, D. C., Cook, H. T., Coppo, R., Haas, M., Liu, C.-H., Roberts, I. S. D., Yuzawa, Y., Zhang, H., Feehally, J., IgAN Classification Working Group of the International IgA Nephropathy Network and the Renal Pathology Society; Conference Participants (2017). Oxford classification of IgA nephropathy 2016: An update from the IgA nephropathy classification working group. Kidney Int., 91 (5), 1014-1021.

\section{IMŪNOGLOBULĪNA A NEFROPĀTIJAS EPIDEMIOLOG̣ISKAIS UN KLĪNISKI MORFOLOĢISKAIS RAKSTUROJUMS LATVIJĀ}

Imūnglobulīna A nefropātija (IgAN) ir visizplatītākais hroniskais glomerulonefrīts ar dažādām klīniskām izpausmēm. Ši pētījuma mērkis bija atklāt IgAN izpausmes Latvijas populācijā, analizējot epidemioloğiskos, klīniskos, histologíiskos datus, un atklāt faktorus, kas varētu ietekmēt slimības gaitu. Tas ir retrospektīvs, viena centra pētījums. Tika iekḷauti IgAN pacienti, kuriem mūsu centrā — Paula Stradiņa Klīniskās universitātes slimnīcas Nefrolog̣ijas centrā piecu gadu laikā tika diagnosticēta IgAN pēc veiktās nieru biopsijas. Tika apkopoti dati no stacionāra un ambulatoriem medicīniskajiem ierakstiem. Pētījumā piedalījās 69 pacienti ar histoloǵiski apstiprinātu IgAN (23\% no visām nieru biopsijām), 52\% vīrieši, vidējais vecums 37 gadi. Vairāk kā pusei no viņiem bija hipertensija, izmainas urīna analīzē un hroniskas izmainas nieru struktūrā, GFR < ml/min pirms biopsijas. Histoloğijas dati, kas stratificēti pēc MEST-C klasifikācijas, bija: M1 (93\%), E1 (5\%), S1 (81\%), T1 un T2 (24\%), C1 (18\%). 17\% sanēma imūnsupresīvu ārstēšanu ar atškirīịiem rezultātiem, 20\% uzsāka nieru aizstājterapiju (NAT). Proteīnūrija, aptaukošanās, hiperurikēmija, augsts kopējais MEST-C rādītājs, zems C3 līmenis serumā bija saistīts ar sliktāku prognozi. Tā kā ievērojama dạa pacientu uzsāka NAT piecu gadu laikā pēc biopsijas, slimības gaita nav labdabīga. IgAN Latvijas iedzīvotājiem tiek diagnosticēta ar progresējošas slimības klīniskajām un histologiiskajām pazīmēm. 